\title{
Freedom of Establishment and the Prohibition of Discrimination in the Internal Market under the Provisions of the Acquis Communautaire
}

\author{
Dr. Senada Reçi \\ University "Luigj Gurakuqi” Shkoder, Albania \\ Dr. Gasper Kokaj \\ University "Luigj Gurakuqi” Shkoder, Albania
}

Doi:10.5901/mjss.2016.v7n3p138

\begin{abstract}
This paper aims to analyze the freedom of establishment in the European Single Market with its features in the context of compliance of member states with the relevant articles of the TFEU. An important part of the provisions on freedom of establishment of companies in the EU are the rules on the types of all forms of discrimination, and his protection is realized by ECJ jurisprudence. The decision of ECJ to test the case of restrictive measures, based on the which was used Gebhard test as part of the research and synthetic analysis analysis occupy a detailed elaboration of this paper.
\end{abstract}

Keywords: freedom of establishment, prohibition of discrimination, principle of equal treatment, internal market, abolition of restrictions.

\section{Introduction}

Freedom of establishment includes the right to take up and pursue activities as self-employed persons and to set up and manage undertakings, in particular, companies or firms.

So freedom of establishment, or as used in the literature of EU law, the right of establishment is the free movement of persons employed.

The legal framework of freedom of establishment which contains fundamental principles, scope and objectives as well as its effects in practice is based:

- $\quad$ First in the Treaty on the Functioning of the European Union, Chapter II, Articles 49-54;

- Second to the General Programme of 18 December 1961 on the abolition of restrictions on freedom of establishment where the removal of restrictions aimed at the mutual recognition of qualifications and coordination of provisional measures about undertaking activities such as provided for in Article 57;

- Third, directives adopted in order to adopt the Articles 49 and following of TFEU and the General Programme, namely directives regarding entry and stay of nationals of Member States and their families, on the facilitation of effective exercise of the right of establishment, on the mutual recognition, on the exceptions due to the exercise of official authority, the ordre public, etc.

The legal basis of the freedom of establishment under Article 49 TFEU is the next to interpret freedom of establishment and the right of establishment, its object and purpose, as well as the consequences for self-employed persons: (Toth. A.G.,Dr.jur.,Ph.D, 2005: 244-247; Mathijsen.P.S.R.F., 2007: 227-229; Kapteyn.P.J.G., Mc.Donell.A.M., Mortelmans.K.J.M., Timmermans.C.W.A. and the late Geelhoed.L.A., 2008: 718-720; Kaczorowska.A. Second edition published, 2011: 714.; Craig.P.,De Burca.G.,EU law text cases and materials, fifth edition, 2011: 771-773; Daniele.L.,Diritto del Mercato Unico Europeo, 2012: 166-174) Within the framework of the provisions set out below, restrictions on the freedom of establishment of nationals of a Member State in the territory of another Member State shall be prohibited. Such prohibition shall also apply to restrictions on the setting-up of agencies, branches or subsidiaries by nationals of any Member State established in the territory of any Member State. Freedom of establishment shall include the right to take up and pursue activities as self-employed persons and to set up and manage undertakings, in particular companies or firms within the meaning of the second paragraph of Article 54, under the conditions laid down for its own nationals by the law of the country where such establishment is effected, subject to the provisions of the Chapter relating to capital. (Article 49 of TFEU: http://eur-lex.europa.eu/legal-content/en/txt/?uri=celex\%3a12012e\%2ftxt). 
From the interpretation of Article 49 we see two forms of accommodation:

i. real right of establishment which occurs when an entity established in a Member State other than home state (or the state in which it was set before), put the center of its only activity, the so-called first establishment Article 49 (1);

ii. right of the opening of agencies, branches or subsidiaries that occur when a subject that is already established in a Member State creates or opens another center of activity in another Member State, the so-called secondary establishment Article 49 (2);

So this legal norm has double meaning, firstly entitles citizens of a Member State of access to activities that are autonomous in the territory of another Member State, making it possible for that to happen through the creation and management of enterprises or companies which hold controlling interest entity, while secondly prohibits the Member State to impose different conditions from those of its citizens .

Therefore interpretation of the second paragraph of Article 49 prohibits any laws of a Member State that hinders/prevents citizens of other Member States to develop certain activities that are lawful independent for its citizens.

\section{Contents of Freedom of Establishment and the Prohibition of Discrimination}

Free movement of employed persons or freedom of establishment is the right of every citizen of a Member State of the EU to follow/exercise an activity:

- economic/commercial and remunerative

- independent/autonomous, of self-employment

- cross-border activity, which means not confined within a Member State, such as the case 134/95 USSL.

- indefinite - to determine whether an undertaking engaged in providing temporary personnel frequently carries out important activities in a Member State in which it is established, the competent institution of that Member State must examine all the criteria characterizing the activities undertaken by the enterprise from it. The control includes the place where the company has its seat and administration, the number of administrative staff that worked in the Member state in which it is established and in other countries, where workers are recruited and the place where the majority of contracts with clients are concluded.

This list can not be exhaustive, the choice of criteria must be adapted to each particular case as in case 202/97 Fitzwilliam.

- A fixed establishment in a Member State of the EU, i.e., continuous and governed by the provisions in question on the deployment and rules on capital for the foreseen in the Treaty provisions on capital as in the case $221 / 89$ Factortame.

A typical example known in the literature of freedom of establishment is the case Reyners, a Dutch citizen who had graduated in law in Belgium, was denied admission to the Belgian Bar only cause he hadn't Belgian nationality. The ECJ ruled that despite the requirements of the Treaty to adopt directives, Article 49 provides an accurate result to be achieved by the end of the transitional period, i.e., the requirement of non-discrimination on grounds of nationality, despite the failure of the Council to adopt the necessary legislation to implement the provisions of the treaty. The fulfillment of this achievement should be done by resorting to Article 49 directly, thus giving direct effect on implementation in Reyners that was discriminated in this case because it was non-Belgian citizen. Reyners case like Van Binsbergen, for the free movement of services, is the case through which the ECJ expanded and clarified the content of the right of establishment and Article 49 and the following.

Besides Reyners, nationality clause occurs in other cases decided by the ECJ as case Commissione c.Grecia concerning the activities of private teaching, 283/88 Commissione c.Italia for monitoring of security companies etc.

It is evidenced in practice the problem if the regulation of a Member State may prohibit the development of activity on its territory, or believe the conditions of monopoly or exclusivity of a national public or private entity (Article 49: http://eur-lex.europa.eu/legal-content/en/txt/?uri=celex\%3a12012e\%2ftxt).

$>$ The answer comes from the jurisprudence of the ECJ about Article 106 of the TFEU which stated that when the conditions laid down, a move of this kind may be regarded as contrary to Article 49 TFEU.

$>$ The exercise of the right of the establishment involved having a permanent presence and continued in the host Member State, which allows a citizen of the EU to participate on a stable and continuous way in the economic life of another Member State.

In connection with legal persons, in case 205/84 Commission v. Germany, the ECJ ruled that a company (in this case an insurance company) was established in a Member State even if its presence is not in the form of a branch or agency, but consists merely of an office managed by undertaking's own staff or by a person who is independent but 
authorized to act on a permanent basis for the enterprise.

The ECJ jurisprudence, has supported analyzed and interpreted Article 49 by establishing the fundamental principles upon which the freedom of establishment should apply to all Member States of the EU to the freedom of establishment parties, which are:

$>$ the principle of equal treatment with nationals or the national treatment principle as we saw in Reyners or equally determined by the Court in Gebhard case.

$>$ direct application of the provisions of the TFEU about freedom of establishment as in case 53/95 Inasti (Right of establishment and freedom to provide services: $h$ ttp://www.abgs.gov.tr/tarama/tarama_files/03/SC03EXP_ Right_of_Establishments.pdf) .

The wording of Article 49 emphasizes the requirement of equal treatment to nationals and non-nationals by Member States, in their right to take up and pursue activities as self-employed persons and to set up and manage undertakings, in particular companies or firms in the same conditions laid down for its citizens in the legislation of the Member State where is such establishment, but does not mention any requirement of direct or indirect discrimination.

Discrimination is prohibited when results of laws, rules, regulations or national practice of the central government, local or regional authorities, professional bodies, or other private organizations of any kind when based on nationality.

Violation of the principle of equal treatment occurs when a Member State allows the exercise of an independent activity of other Member States, but set conditions less favorably than those of its own nationals, through certain national provisions and it is called direct discrimination. There are numerous cases of violation of this principle to constitute direct discrimination cases on the right of establishment of nationals of other Member States as such we can mention case $197 / 84$ Steinhauser which has to do with the decision of a French municipality to allow the use of domestic premises only for artists of French nationality.

Likewise, in other cases, the ECJ has ruled that a Member State fails to fulfill its obligations under Article 49 TFEU when:

- gives access to certain professions for citizens of another Member State by reciprocity

-requires the possession of its nationality as a condition for access to and exercise of certain professions or activities

-it allows only its nationals to set up several companies, or to participate in competitions for obtaining licenses for the practice of some businesses

-it makes it more difficult for nationals of other Member States registering as a member of professional bodies where such registration is a prerequisite for facilitating its access to the exercise of certain professions

-requiring directors and managers of some enterprises to reside in its territory

-requires only nationals of other Member States, not its citizens, live in its territory to obtain the necessary authorization to initiate or pursue some activities, etc.

There are cases of obstacles to the right of the opening of subsidiaries in the sector of liberal professions, such as case Klopp, a German lawyer was refused admission to the Chamber of Advocates of Paris on condition that he held an office as a lawyer in another Member State, and the ECJ ruled that Article 49 guarantees precisely the freedom to settle in more than one Member State of the EU and had less restrictive ways as transportation and telecommunications that you provide advocates maintaining continuous contacts with their clients and the judicial authorities and to obey the rules of the profession.

Klopp was not an authority, and non-discriminatory rules could constitute a violation of Article 49 , which explicitly guarantees the right to a secondary establishment, cause, in this case, is denied but shows that freedom of establishment in some circumstances require more than equal treatment.

In cases Wolf, Stanton, and Kemmler, the Court decided that "some national measures applicable without distinction, on exclusion of social insurance for the self-employed were inadmissible, since they constitute a barrier to unjustified prosecution activities working in more than one Member State, although the rules do not contain direct or indirect discrimination concerning nationality".

But it should be noted that the decision Gebhard (Gebhard was a German citizen against whom had disciplinary proceedings in the Bar of Milan for pursuing a professional activity as a lawyer in Italy on a permanent basis. He had created/opened his legal offices under the title advocate, although it was not accepted on the Bar of Milan cause training, qualifications and his experience were not formally recognized in Italy) is the best indicator of broad interpretation of Article 49 TFEU, since here the Court stated that the same principles underpin all the provisions of the Treaty on freedom of movement and declared that the provisions on goods, services, workers, and placement will be interpreted the same way, which means that any rule that prevents or makes less possible exercise of freedom of establishment (and other freedoms community) can violate the Treaty unless justified by a requirement mandatory or not apply the proportionality 
or non-discriminatory test, the Van Binsbergen test (Craig.P.,De Burca.G., 2011: 774-775).

\section{Gebhard Test and Its Effects on the Implementation of National Legislation}

Gebhard test, imposed by the ECJ, is the test that had striking effects on national legislation as Gebhard case decision should be applied when national rules are applicable without distinction. Restrictive measures should protect the freedom of establishment and this test provides the fulfillment of 4 conditions:

i. implemented in a non-discriminatory way

ii. be justified by overriding reasons of public interest

iii. be appropriate to ensure the continuation of the aim pursued

iv. not go beyond what is necessary to achieve the purpose (Daniele.L., 2012: 187-189).

It must be underlined that forms of direct or indirect discrimination in the freedom of establishment are more varied or multidimensional. Direct discrimination on freedom of establishment is when a Member State determines that a given activity should be conducted by a company which has its registered office or principal establishment in its territory. Such rule prohibits firms from the other Member States in the use of forms of accommodation such as branches or agencies and thus discriminates against them by inflicting the imposition of additional costs such as the cost of creating a new company that locals should not pay in this case. This requirement is not justified by the need for effective surveillance, control or sanction the activity in question when these objectives can be achieved by less restrictive measures. As an example of jurisprudence, we have case 101/94 Commission v.Italy.

However, the prohibition of direct discrimination is not limited to the specific rules regarding access and tracking of professional activities but also on non-discrimination in the facilities of the various assistance in the prosecution of these outreach activities such as; the right to use, dispose or acquire a movable or immovable property in the territory of the host country, the right to obtain loans, the right to social benefits like maternity or pregnancy, special benefits for large families as in case 111/91 Commission v.Luxembourg, or case 185/96 Commission v.Greece, income taxation, the right to participate in tenders for the award of public property, such as in case 197/84 Steinhauser where foreigners were excluded from a tendering procedure for the award of public property use for business purposes etc.

Based on the General Program on the abolition of restrictions on freedom of establishment, the ECJ noted that a national of a Member State wishing to pursue an activity as self-employed person in another Member State should be able to find accommodation, including the social one, in the same conditions as nationals of the host country, including financial facilities for this purpose (Toth. A.G.,Dr.jur.,Ph.D, 2005: 255-257).

The freedom of establishment prohibits any form of discrimination included indirect discrimination or the reverse discrimination.

\section{The Principle of National Treatment to the Freedom of Establishment}

Nationals of a Member State are entitled to exercise the right to decide whether or not reside within the territory of the EU. However, nationals of a third country residing legally in a Member State can not rely on Article 49 of the TFEU in order to settle in another Member State unless they are covered by Directive 2003/109/EC concerning the status of citizens of third countries who are long-term residents if they come within the definition of a family member of a citizen of the EU, which carries one of the four freedoms community or international agreements concluded between the EU and their country of origin (Toth. A.G.,Dr.jur.,Ph.D, 2005: 249-251; Kaczorowska.A., 2011: 715-716; Mathijsen.P.S.R.F., 2007: 229-231).

The principle of national treatment may be violated even if a legal norm is applied equally to both locals and nationals of other Member States and in fact, the latter is treated equally disadvantaged precisely because they are treated same as nationals.

Indirect discrimination to freedom of establishment is when although the requirements set by the law of a Member State in connection with the pursuit of an activity as self-employed are the same as for natives and citizens of other Member States, and their implementation without primary citizenship is intended exclusively or mainly to prevent undertaking such activity by foreign nationals such as in case 71/76 Thieffry. This discrimination although applies regardless between nationals and foreigners, primarily favors locals putting such conditions that can be achieved more quickly by locals than foreigners, such as in case 3/88 Commission v.ltaly or case 337/97 Meussen. In Meussen case Dutch legislation requirement of citizenship as a condition for obtaining a scholarship of studies to children of nationals of other Member States, made ECJ ruling that; 'a dependent child of a national of a Member State who pursues an activity as a self-employed person in another Member state, while maintaining his residence in his original state, can get funding 
to study under the same conditions as are applicable to children of nationals of the state of establishment, and in particular without any further requirements, such as place of residence of the child' (Ibid: 257).

While Article 49 TFEU does not apply in situations wholly internal, it does not prevent reverse discrimination, ie the strict imposition of conditions or less favorable conditions for its nationals than to citizens of other Member States.

For example in case Werner, the ECJ indicated that a citizen who is resident in a Member State other than the country of its origin, so long as he held the place of establishment of his professional practice in his country of origin can not rely in Article 49, to challenge the payment of state taxes favoring its residents against non-residents.

So in the absence of harmonizing or coordinating measures at Community level can not be considered contrary to Article 49 TFEU the request for a citizen to its citizens to have a degree to practice a particular activity when it allows citizens of other Member States to exercise the same profession in question without a diploma. Eg. to the question we have case Aubertin, where a French citizen to work in France as a hairdresser's and be placed as such, required a degree in hairdressing. Meanwhile, Directive $82 / 489$ provides for the Member States measures to facilitate the effective exercise of the right of establishment and freedom to provide services in hairdressing, where six years of professional experience, is enough to exercise the profession in the host country. However, a French hairdresser, who did not pass the test to become hairdresser can not rely on the experience of his/her six years in France to practice and is undergoing reverse discrimination.

The explanation is that Directive $82 / 489$ does not harmonize the conditions of access to the hairdressing profession in the Member States. So the phenomenon of reverse discrimination occurs when nationals of a Member State are treated at a disadvantage with nationals of other Member States within the same Member State.

In case Belgian social security, the Flemish government, a federated entity of the Belgian state adopted a care insurance scheme that was available only to those who lived and worked in the Dutch-speaking province in the bilingual region of Brussels-capital (Bruxelles- Capitale). In fact, in this case discrimination is against citizens of the province's French-speaking people who have suffered reverse discrimination, while living and working in the same region (Toth. A.G.,Dr.jur.,Ph.D, 2005: 257-259; Craig.P.,De Burca.G, 2011: 776-778). The ECJ ruled that this constitutes a restriction under Article 45 and 49 TFEU since migrant workers who pursue an activity of employment or self-employment in one of these regions, if they move in the other province are excluded from the benefit in question and will lose the right as a beneficiary of the scheme.

Therefore the Court ruled that the right of EU can not be applied to situations wholly internal, because if it happens, in this case, a Spanish citizen who is established in the French-speaking province and working in the Dutch-speaking one would benefit insurance scheme while his Belgian colleague and neighbor could not cause lived and worked all his life in Belgium.

Direct and indirect discrimination is prohibited in the field of taxation, and the ECJ stated in a row of cases that despite direct taxation is within the competence of the Member States, they must apply this power continuously by Community law and avoid any private or open discrimination based on nationality in the field of taxation.

In case Asscher, a Dutch citizen resident in Belgium, who was director of companies in Belgium and the Netherlands, and that the account status as non-resident/resident and income levels outside the Netherlands was subject to the Netherlands a more significant level higher taxes than residents there, was entitled to rely on Article 49 TFEU against his Member State. But except on the basis of nationality, is prohibited even when the seat is based on joint stock companies where, as in the case 251/98 Baars that has to do with the Dutch legislation that allowed citizens of the community that lived in the Netherlands to be exempted from property tax in relation to the assets invested in shares in companies established in the Netherlands, but denied this exception to the shareholders in companies established in other Member States.

Thus, Article 49 regulates the establishment and its forms banning restrictions on the conduct of activities of selfemployment and discrimination of its kind implemented in practice by the Member States, as in the case of nonimplementation of the right of the EU, or in the case of implementation of domestic (national) norms not in accordance with community law.

\section{Conclusions}

Freedom of establishment is a form of self-employment, renumerative, cross-border activity, but differs from the free movement of services based on two characteristics, and more specifically the duration of the activity, which is constant in time and with a placement fixed in a Member State of the EU and regulated by provisions on the establishment.

In the removal of restrictions has contributed jurisprudence of the ECJ with case 2/74 Reyners extending understanding and clarifying the content of Articles 49-55 TFEU on freedom of establishment and giving them direct 
effect. Both provisions are subject to the principle of non-discrimination based on grounds of nationality.

National rules which are directly discriminatory can be justified only by the definition in the Treaty. Nondiscriminatory rules may be justified in some circumstances.

The prohibition of direct and indirect discrimination is provided in the Treaty, and freedom of establishment and restrictions on freedom can be justified only on grounds of ordre public and the exercise of public authority official.

There are also prohibited all national measures aimed at hinder or render less attractive the right of establishment in the Single market and at Gebhard judgment, the Court stated that the same principles underpin all the provisions of the Treaty on freedom of movement. Here the ECJ said that the provisions on goods, services, workers, and the establishment will be interpreted the same way, which means that any rule that prevents or makes less possible exercise of freedom of establishment will be justified if they meet four criteria established by ECJ respectively Gebhard test.

\section{References}

Toth. A.G.,Dr.jur.,Ph.D, The Oxford Encyclopaedia of European Community Law, volume II The law of the Internal market, Oxford University Press, 2005.

Mathijsen.P.S.R.F.,A guide to European Union Law, London Sweet and Maxwell, 2007.

Kapteyn.P.J.G., Mc.Donell.A.M., Mortelmans.K.J.M., Timmermans.C.W.A. and the late Geelhoed.L.A., The law of the European Union and the European Communities with reference to changes made by the Lisbon Treaty, fourth revised edition; Kluwer Law International, 2008.

Kaczorowska.A.,European Union Law, Second edition published, 2011, by Routledge.

Craig.P.,De Burca.G.,EU law text cases and materials, fifth edition, Oxford University Press 2011.

Daniele.L.,Diritto del Mercato Unico Europeo, seconda edizione, Giuffré Editore, 2012.

Right of establishment and freedom to provide services, European Commission, Internal Market and Services DG: http://www.abgs. gov.tr/tarama/tarama_files/03/SC03EXP_Right_of_Establishments.pdf

Article 49 of TFEU Consolidated versions of the Treaty on European Union and the Treaty on the Functioning of the European Union 2012/C 326/01: http://eur-lex.europa.eu/legal-content/en/txt/?uri=celex\%3a12012e\%2ftxt 